\title{
Radiology learning or teaching subject areas vs modalities: students' perspective and experience at Albaha University
}

This article was published in the following Dove Press journal:

Advances in Medical Education and Practice

\section{Fahd Nasser AIQahtani}

Radiology Department, Faculty of Medicine, Albaha University, Albaha, Saudi Arabia
Correspondence: Fahd Nasser AlQahtani Radiology Department, Faculty of Medicine, Al Baha University, Alaqiq Road, Alaqiq, Albaha Governorate, Saudi Arabia

Tel +966549999427

Email fnqatt@gmail.com
Introduction: In radiology learning, most of the integrated schools address the subject area as a theme, and several imaging modalities describe the findings. A few schools handle the imaging modalities as a separate theme wherein many subject areas are discussed.

Purpose: The aim of this study was to identify the differences in student achievement in imaging course using the two learning approaches: integration within modalities under the subject area and integration within the subject area under imaging modalities.

Materials and methods: This study was conducted on 60 students studying the basic imaging course. Students were divided into two main groups; group A and B. Contents were divided into two main categories: subject areas and imaging modalities. 1) Subject areas were applied according to body systems such as imaging of the central nervous system (CNS) and, cardiovascular system (CVS). 2) Modalities were addressed as plain X-ray and computed tomography (CT) which were separate entities comprising the findings of the most common diseases. The two groups learned the both approaches in a sequential alternative manner for 10 days by the same radiological group experts. A 60-question final examination was adopted at the end of the module including 30 questions for each approach. The students' and peers' satisfaction was measured using Likert scale.

Results: A high response from the students toward the second approach has been found. The students' grades in the second model examination reflecting the second approach were found elevated. The students' and peers' satisfaction toward the second approach was high compared with the first approach with highly significant $P$-value obtained.

Conclusion: This experience advocated that the perception of students toward radiology teaching can be enhanced when focused on a single imaging modality for a time. Students can identify and augment more images and do multiple comparisons with the pre and post ones. The students' and peers' satisfaction was found to be high toward the imaging modality approach.

Keywords: basic imaging, guided imaging learning, comparative imaging modalities, integrated imaging, student perspectives

\section{Introduction}

Basic imaging module for undergraduate students was implemented in Albaha School of Medicine (ABSM) 5 years ago. The teaching strategy was adopted to match the achievement of learning outcomes. In the basic imaging module of ABSM, the subject area was addressed and handled by different imaging tools.

The periodic evaluation of the module revealed some points which must be discussed and managed. Of these, the approach of integration within the module showed some conflicts that were obtained from students' and peers' inference. The conflict has to be resolved on answering the applied question which is the best teaching sub- 
ject area with different diagnostic imaging modalities, for example, chest infection is the subject area and subsequent imaging findings such as chest X-ray findings, computed tomography (CT) findings, and magnetic resonance imaging (MRI) findings. Alternatively, the imaging can be learned by separate modalities in which different subject areas were taught, for example, chest X-ray in different chest problems as pneumonia, bronchial asthma, effusion, cardiac problems, or CT findings in different chest diseases. The first approach denotes integration of all diagnostic tools under one subject area to reach the diagnosis while the second approach represents the integration of the subject area under one diagnostic tool.

Reviewing the imaging curriculum among medical schools revealed a diversity of the teaching strategy as some prefer to address the subject area and others prefer to apply the imaging tool as a title. Most of these schools have their own course depending on a particular medical school; entire educational programs and, in particular, the undergraduate radiology course, are different in terms of the curricular content, human resources, and instructional formats. The student satisfaction and choice of career in the future depend on, to a large extent, the approach of delivery of knowledge, better understanding of the content, and selection of appropriate teaching tools. ${ }^{1,2}$

The aim of this study was to identify the differences in student achievement in imaging course using the two learning approaches: integration within modalities under the subject area or integration within the subject area under imaging modalities.

\section{Materials and methods}

This study was done after obtaining permission from the Quality and Accreditation Unit of the College Agency for Quality Affairs of ABSM, Albaha University, and also after obtaining the written approval of all the participating students after being informed of the purpose of the study.

This case-control study was conducted on 60 students who represented the total class of the fourth iteration of students in whom the course of the basic imaging module was implemented. The 60 students were classified into two groups: group A and group B, with 30 students each according to their performance in the previous levels. The students were arranged according to their total marks in the previous levels; these total marks were expressed in grades ranged from $\mathrm{A}$ to $\mathrm{D}$ in nearly approximated numbers. Hence, each group included all grades ranged from $\mathrm{A}+$ to $\mathrm{D}$. The details of the students' grades are summarized in Table 1.
Table I Grading in the previous levels of the participating students in the present study

\begin{tabular}{|l|l|l|}
\hline Grade & Group A & Group B \\
\hline A & 7 & 6 \\
\hline B & 6 & 7 \\
\hline C & 12 & 13 \\
\hline D & 5 & 4 \\
\hline Total & 30 & 30 \\
\hline
\end{tabular}

Contents were divided into two main components: subject areas and imaging modalities. 1) Subject areas were applied according to body systems such as imaging of the central nervous system (CNS), chest, cardiovascular system (CVS) and, genitourinary system, and 2) modalities were addressed as plain X-ray, CT, MRI, ultrasound (US), and different contrasts. These modalities covered all body systems in separate entities. Each component had a total of 1.5 credit hours equally implemented in two successive 10 days. The contents of both approaches are presented in Table 2 .

For approach 1, the subject area was addressed, which was a brief description about the definition, clinical picture, and list of differential diagnosis (DD); then, the radiological findings from several imaging modalities were heavily discussed according to the list of the DD of the subject area, for example, acute abdominal pain was the theme or the subject area; the instructor gave brief description about the definition and clinical picture, and the students were asked to list the DD. After listing the DD, the instructor explained the radiological findings for each using multiple modalities starting with most common and simple as plain X-ray; then U/S, CT, MRI, and other radiological modalities were available. For approach 2, the modality such as plain X-ray or CT or others was addressed in relation to body systems; then, the instructor explained normal and abnormal findings and matched the abnormal findings with their combatable disease, for example, abdominal U/S, and also explained the normal findings and common abnormal findings related to hepatobiliary system and urinary system and made discussion with the students about how to match these findings to reach the accurate diagnosis.

The two groups studied the imaging course using the two approaches in an alternative sequential manner (Table 3 ).

Both approaches were taught by the same radiological experts. A well-designed final written examination that included 60 questions was adopted at the end of the basic imaging module implying two models of questions designed for both approaches arranged in a haphazard and 
Table 2 Subject areas and modalities used in teaching the radiology course that represent the two approaches

\begin{tabular}{|c|c|c|}
\hline System & Subject areas (approach I) & Modalities (approach 2) \\
\hline $\begin{array}{l}\text { GIT, pelvis, urinary } \\
\text { system, and } \\
\text { reproductive system }\end{array}$ & $\begin{array}{l}\text { Abdominal trauma } \\
\text { Acute abdominal pain } \\
\text { Abdominal distension } \\
\text { Change in bowel habits } \\
\text { Colorectal cancer } \\
\text { Different hepatic lesions including jaundice } \\
\text { Obstruction and perforation } \\
\text { Urinary retention } \\
\text { Urinary tract infection } \\
\text { Renal colic } \\
\text { Gynecological emergencies and testicular lesions }\end{array}$ & $\begin{array}{l}\text { Interpretation of abdominal X-ray } \\
\text { Plain X-ray findings in different GIT lesions } \\
\text { Interpretation of abdominal and pelvic U/S } \\
\text { U/S findings in different abdominal and pelvic lesions } \\
\text { Interpretation of abdominal and pelvic CT } \\
\text { CT findings in different GIT lesions } \\
\text { Interpretation of abdominal and pelvic MRI } \\
\text { MRI findings in different GIT lesions } \\
\text { Contrast, types, indications, and adverse effects } \\
\text { Interpretation of contrast film in abdominal and pelvic lesions } \\
\text { HSG, indications, and interpretation }\end{array}$ \\
\hline $\begin{array}{l}\text { Central nervous } \\
\text { system }\end{array}$ & $\begin{array}{l}\text { Head injury and stroke } \\
\text { Intracranial hemorrhage } \\
\text { Cord compression syndromes } \\
\text { Altered consciousness levels } \\
\text { Neck injury and backache } \\
\text { Brain tumors } \\
\text { CNS infection }\end{array}$ & $\begin{array}{l}\text { Interpretation of head and neck X-ray } \\
\text { Plain X-ray findings in different cranial and neck lesions } \\
\text { Indications and interpretation of cranial U/S especially in neonates } \\
\mathrm{U} / \mathrm{S} \text { findings in different cranial lesions } \\
\text { Interpretation of cranial and neck CT } \\
\mathrm{CT} \text { findings in different cranial lesions } \\
\text { Interpretation of MRI brain and neck } \\
\text { MRI findings in different cranial and neck lesions } \\
\text { Contrast, types, indications, and adverse effects } \\
\text { Interpretation of contrast film in cranial lesions }\end{array}$ \\
\hline $\begin{array}{l}\text { Respiratory system } \\
\text { and chest }\end{array}$ & $\begin{array}{l}\text { Breathless and chest pain } \\
\text { Chest infection and cough } \\
\text { Congestive cardiac failure } \\
\text { Thoracic trauma and pneumothorax } \\
\text { Pleural and pulmonary tumors } \\
\text { Hemoptysis and pulmonary embolism }\end{array}$ & $\begin{array}{l}\text { Interpretation of chest X-ray } \\
\text { Plain X-ray findings in different chest lesions } \\
\text { Interpretation of chest CT } \\
\text { CT findings in different pulmonary lesions } \\
\text { Interpretation of chest MRI } \\
\text { MRI findings in different pulmonary and pleural lesions }\end{array}$ \\
\hline CVS & $\begin{array}{l}\text { Aortic anomalies and diseases including valvular } \\
\text { diseases } \\
\text { Ischemic heart diseases } \\
\text { Cardiothoracic problems in infancy and childhood } \\
\text { including congenital heart disease }\end{array}$ & $\begin{array}{l}\text { Interpretation of cardiac X-ray } \\
\text { Plain X-ray findings in different cardiac lesions including valvular } \\
\text { heart diseases } \\
\text { Interpretation of cardiac CT } \\
\text { CT findings in different cardiac lesions } \\
\text { Interpretation of cardiac MRI } \\
\text { MRI findings in different cardiac lesions } \\
\text { Echo, indications, basic knowledge, angiogram, and Doppler U/S }\end{array}$ \\
\hline MSK & $\begin{array}{l}\text { Trauma and non-accidental injury } \\
\text { MSK infections } \\
\text { Congenital anomalies and metabolic bone diseases } \\
\text { MSK tumors } \\
\text { Chronic arthritis }\end{array}$ & $\begin{array}{l}\text { Plain X-ray interpretation } \\
\text { Plain X-ray findings in MSK lesions } \\
\text { Interpretation of MSK CT } \\
\text { CT findings in different MSK lesions } \\
\text { Interpretation of MRI related to MSK } \\
\text { MRI findings in different MSK lesions }\end{array}$ \\
\hline
\end{tabular}

Abbreviations: CNS, central nervous system; CT, computed tomography; CVS, cardiovascular system; GIT, gastrointestinal tract; HSG, hysterosalpingogram; MRI, magnetic resonance imaging; MSK, musculoskeletal; U/S, ultrasound; GIT, gastrointestinal; MSK, muscloskeletal system.

Table 3 Distribution of the student groups in relation to course days and approach type

\begin{tabular}{|l|l|l|}
\hline Course days & Group A & Group B \\
\hline I-10 days & Approach I & Approach 2 \\
\hline I I-20 days & Approach 2 & Approach I \\
\hline
\end{tabular}

an anonymous manner. Model 1 represented approach 1 which expressed teaching by the subject area while model 2 represented approach 2 which expressed teaching through imaging modalities. These questions were coded against the type of approach to be easily recognized. The examination was conducted by the teaching staff to value its validity/reliability. The grading of students was considered as follows: $\geq 95 \%$ was graded as $A+, \geq 90-94$ was graded as $A, \geq 85-89$ was graded as $\mathrm{B}+, \geq 80-84$ was graded as $\mathrm{B}, \geq 75-79$ was graded as $\mathrm{C}+, \geq 70-74$ was graded as $\mathrm{C}, \geq 65-69$ was graded as D+, $\geq 60-64$ was graded as D, and $<60$ was graded as F. Examples of questions applied for both approaches are listed as follows: 
Examples of questions applied for approach 1

1. All the following are DD of periosteal reaction except:
a) Malignant tumor
b) Infection
c) Iron deficiency anemia
d) Congenital syphilis

2. All the following are "true" regarding cephalohematoma except:
a) Can be seen between the skull and dura
b) Fracture not always seen
c) Most common in frontal region
d) Water density up to 2 weeks

3. Pancreatic calcification is seen in all the following except:
a) Kwashiorkor
b) Acute pancreatitis
c) Hypoparathyroidism
d) Mucoviscidosis

4. All the following pathologies cause wide mediastinum except:
a) Left atrial enlargement
b) Thoracic aortic aneurysm
c) Retrosternal goiter
d) Hilar lymphoma

5. The fractures of descending transtentorial herniation have all the following except:
a) Hemorrhage in midbrain on the opposite side
b) Effacement of ipsilateral suprasellar cistern
c) Widening of ipsilateral cerebellopontine (CP) angle cistern
d) Obliteration of all basal cisterns

6. All the following are "incorrect" regarding corpus callosal agenesis except:
a) The frontal horns are concave if the genu is absent
b) Colpocephaly if the splenium is present
c) The internal cerebral veins are separated
d) U shaped in the vein of Galen

7. Thumbprinting is seen in all the following except:
a) Amebic colitis
b) Schistosomiasis
c) Ischemic colitis
d) Pneumatosis coli

8. Skip lesions are seen in all the following except:
a) Tuberculosis
b) Amebiasis
c) Ulcerative colitis
d) Crohn's disease

Examples of questions applied for approach 2

9. Which of the following is contraindicated for endoscopic retrograde cholangiopancreatography?
a) Acute cholecystitis
b) HIV-positive patient
c) Pseudocyst of pancreas
d) Pyloric stenosis

10. Contraindication for emergency barium enema is:
a) Toxic megacolon
b) Obstruction
c) Portal venous gas
d) Pneumatosis intestinalis

11. Plain film of the abdomen

a) The kidneys-ureters-bladder is often the first imaging study performed to visualize the abdomen and urinary tract

b) The film is taken with the patient supine and should "not" include the entire abdomen from the base of the sternum to the pubic symphysis

c) "Cannot" show bony abnormalities, calcification, and large soft tissue masses

d) Contrast martial can be used in it

12. The main indications of CT in the urinary tract are the following except:

a) To demonstrate renal masses and staging renal tumors

b) To delineate renal vascular anatomy

c) To diagnose or exclude renal trauma

d) To demonstrate urinary tract infections

13. Which of the following radiological signs favor pleural effusion rather than consolidation?
a) Presence of air bronchogram
b) Obliteration of the costophrenic angle
c) Air fluid level within the lung shadow
d) Hyperinflated lungs

14. Disruption of Shenton line may be associated with which of the following conditions:
a) Hip dislocation
b) Shoulder dislocation
c) Prostate metastasis
d) Diagnostic of osteosarcoma

15. Pneumatosis intestinalis is a characteristic radiological sign of:
a) Intestinal obstruction
b) Achalasia
c) Intussusception
d) Necrotizing enterocolitis 
16. Coin test is a radiological test used to diagnose:

a) Volvulus

b) Pyloric stenosis

c) Imperforate anus

d) Hiatus hernia

At the end of the course, a well-formed, valid structured questionnaire has been designed by the committee to evaluate the course as a whole and particularly the course outcome. The committee was formed by the staff members of radiology and pathology in collaboration with medical education staff experts. The questions were formulated and revised thoroughly by the educational experts to give the validity of this questionnaire. In addition, a pilot study was done on two separate groups: one group represented junior staff members and the other group represented 60 students of level IV. The results of both groups were close to each other. This pilot study confirmed that the questionnaire was reliable to be used. The questionnaire was distributed to all the 60 students and designed to measure the grades of acceptance and satisfaction among students about the approach of integration within the basic imaging module.

The questionnaire had five grades according to the Likert scale $^{3-6}$ and measured the degree of satisfaction of students regarding the domains of the module, so the scale ranged from strongly dissatisfied to strongly satisfied that formed the two extremities of the questionnaire. Rating scale was used which ranged from 1 to 5 . The students marked the number applied in front of each scale. The whole Likert scale applied for the imaging module including the evaluation of course outcome is listed in Table 4 as follows:

Table 4 Likert scale questionnaire for measuring the degree of students' satisfaction about both modalities used in teaching/ learning the basic imaging course in the present study

\begin{tabular}{|c|c|c|c|c|c|}
\hline Evaluation Domains & $\begin{array}{l}\text { Strongly } \\
\text { dissatisfied }\end{array}$ & Dissatisfied & Neutral & Satisfied & $\begin{array}{l}\text { Strongly } \\
\text { satisfied }\end{array}$ \\
\hline \multicolumn{6}{|l|}{ I. Course organization and planning } \\
\hline The module identified learning objectives and method of grading & $\mathrm{I}$ & 2 & 3 & 4 & 5 \\
\hline The content was matched with the stated course objectives & 1 & 2 & 3 & 4 & 5 \\
\hline The content was arranged in a clear and orderly manner & 1 & 2 & 3 & 4 & 5 \\
\hline \multicolumn{6}{|l|}{ 2. Communication } \\
\hline $\begin{array}{l}\text { The instructor explained the course material in a way that you could } \\
\text { understand }\end{array}$ & 1 & 2 & 3 & 4 & 5 \\
\hline The instructor showed enthusiasm for the subject matter & 1 & 2 & 3 & 4 & 5 \\
\hline The instructor maintained a respectful and professional learning environment & $\mathrm{I}$ & 2 & 3 & 4 & 5 \\
\hline You were encouraged to ask questions & 1 & 2 & 3 & 4 & 5 \\
\hline You were given meaningful answers to your questions & 1 & 2 & 3 & 4 & 5 \\
\hline The instructor was concerned with student learning & 1 & 2 & 3 & 4 & 5 \\
\hline $\begin{array}{l}\text { The instructor was available for course-related questions at office hours or } \\
\text { by e-mail }\end{array}$ & 1 & 2 & 3 & 4 & 5 \\
\hline \multicolumn{6}{|l|}{ 3. Assignments/examinations and graded materials } \\
\hline $\begin{array}{l}\text { The course's assignments (readings, problem sets, essays, projects, reports, } \\
\text { in-class exercises, etc.) helped you learn }\end{array}$ & 1 & 2 & 3 & 4 & 5 \\
\hline $\begin{array}{l}\text { Graded materials (examinations, quizzes, assignments, reports, projects, } \\
\text { etc.) reflected what was taught in the course }\end{array}$ & I & 2 & 3 & 4 & 5 \\
\hline $\begin{array}{l}\text { The course's assignments (readings, problem sets, essays, projects, reports, } \\
\text { in-class exercises, etc.) helped you learn }\end{array}$ & 1 & 2 & 3 & 4 & 5 \\
\hline \multicolumn{6}{|l|}{ 4. Instructional methods } \\
\hline The instructor provided timely feedback on assignments & $\mathrm{I}$ & 2 & 3 & 4 & 5 \\
\hline $\begin{array}{l}\text { The instructor used teaching methods (discussion, lecture, demonstration, } \\
\text { etc.) that enhanced your learning }\end{array}$ & 1 & 2 & 3 & 4 & 5 \\
\hline The instructor made appropriate and effective use of technology & $\mathrm{I}$ & 2 & 3 & 4 & 5 \\
\hline The instructor used class time effectively & 1 & 2 & 3 & 4 & 5 \\
\hline \multicolumn{6}{|l|}{ 5. Course outcomes } \\
\hline You learned the key concepts you studied in this course & $\mathrm{I}$ & 2 & 3 & 4 & 5 \\
\hline $\begin{array}{l}\text { You learned the normal and abnormal radiological findings under one } \\
\text { subject area using different modalities in a sequential manner }\end{array}$ & 1 & 2 & 3 & 4 & 5 \\
\hline $\begin{array}{l}\text { You learned the normal and abnormal radiological findings under one } \\
\text { imaging modality with different subjects arranged in a sequential manner }\end{array}$ & 1 & 2 & 3 & 4 & 5 \\
\hline You use one imaging modality to subject area to understand and report & $\mathrm{I}$ & 2 & 3 & 4 & 5 \\
\hline $\begin{array}{l}\text { You learned the imaging interpretation through collection of multiple } \\
\text { subjects under one imaging modality }\end{array}$ & I & 2 & 3 & 4 & 5 \\
\hline
\end{tabular}

(Continued) 
Table 4 (Continued)

\begin{tabular}{|c|c|c|c|c|c|}
\hline & $\begin{array}{l}\text { Strongly } \\
\text { dissatisfied }\end{array}$ & Dissatisfied & Neutral & Satisfied & $\begin{array}{l}\text { Strongly } \\
\text { satisfied }\end{array}$ \\
\hline $\begin{array}{l}\text { You learned the radiological interpretation by understanding the DD of } \\
\text { subject applied }\end{array}$ & I & 2 & 3 & 4 & 5 \\
\hline $\begin{array}{l}\text { You learned the radiological interpretation by understanding the lesions } \\
\text { through sequences of imaging modalities }\end{array}$ & $I$ & 2 & 3 & 4 & 5 \\
\hline $\begin{array}{l}\text { Most subject areas need more imaging modalities to understand, analyze, } \\
\text { compare, and report at the same time of learning }\end{array}$ & $\mathrm{I}$ & 2 & 3 & 4 & 5 \\
\hline $\begin{array}{l}\text { You can select the most common and noninvasive modality to understand } \\
\text { and report most of the subject areas in the course content }\end{array}$ & $I$ & 2 & 3 & 4 & 5 \\
\hline $\begin{array}{l}\text { Using different modalities in the same setting for one subject area is of great } \\
\text { importance to understand }\end{array}$ & I & 2 & 3 & 4 & 5 \\
\hline $\begin{array}{l}\text { Using different subjects in the same setting for one imaging modality is of } \\
\text { great importance to understand }\end{array}$ & $I$ & 2 & 3 & 4 & 5 \\
\hline $\begin{array}{l}\text { You used high-level thinking in this course (eg, analyzing ideas, synthesizing } \\
\text { ideas, making judgments about information, and applying information to new } \\
\text { situations) }\end{array}$ & I & 2 & 3 & 4 & 5 \\
\hline $\begin{array}{l}\text { Your perspective expanded (eg, intellectually, culturally, and artistically) } \\
\text { about the materials you studied in this course }\end{array}$ & $\mathrm{I}$ & 2 & 3 & 4 & 5 \\
\hline Your interest in this subject has increased as a result of this course & $\mathrm{I}$ & 2 & 3 & 4 & 5 \\
\hline \multicolumn{6}{|l|}{ 6. Course workload } \\
\hline You put effort into learning the materials covered in this course & $\mathrm{I}$ & 2 & 3 & 4 & 5 \\
\hline You were challenged to do your best work in this course & 1 & 2 & 3 & 4 & 5 \\
\hline
\end{tabular}

Abbreviation: DD, differential diagnosis.

The main statistical studies were done using $t$-test. SPSS version 17 (SPSS Inc., Chicago, IL, USA) was applied for the current study. $P$-value was considered significant if $\leq 0.05$.

\section{Results}

Regarding students' degrees, the number of students entered the quiz was 60 for both approaches. The degrees ranged from $\mathrm{A}+, \mathrm{A}, \mathrm{B}+, \mathrm{B}, \mathrm{C}+, \mathrm{C}, \mathrm{D}+, \mathrm{D}$, and $\mathrm{F}$. The students' degrees for approach 1 were as follows: 1 (1.6\%), 4 (6.6\%), 5 (8.3\%), 7 (11.6\%), 10 (16.6\%), 14 (23.3\%), 12 (20\%), 5 (8.3\%), and $2(3.3 \%)$ compared with $4(6.6 \%), 8(13.3 \%), 12(20 \%), 17$ (28.3\%), 5 (8.3\%), 7 (11.6\%), 5 (8.3\%), 1 (1.6\%), and 1 (1.6\%) for approach 2. Global comparison among all grades was done, and a highly significant $P$-value was obtained $(P$-value $=0.0001 ;$ Table 5 and Figure 1$)$.

Regarding students' satisfaction using Likert scale, the students showed all degrees of satisfaction which ranged from strongly satisfied, satisfied, neutral, dissatisfied, and strongly dissatisfied as follows: for approach 1: 16/60 (26,6\%), 22 (36.6\%), 7 (11.6\%), 7 (11.6\%), and 8 (13.3\%) compared with $27(45 \%), 18(30 \%), 3(5 \%), 8(13.3 \%)$, and 4 (6.6\%) for approach 2. Global comparison among all grades was done, and a highly significant $P$-value was obtained ( $P$-value $=0.0001$; Table 6 and Figure 2).

Regarding peers' satisfaction using Likert scale, the peers showed all degrees of satisfaction which ranged from strongly satisfied, satisfied, neutral, dissatisfied, and strongly dissatisfied as follows: for approach 1: 3/15 (20\%), 4 (26.6\%), 1 (6.6\%), 4 (26.6\%), and 3 (20\%) compared with 7 (46.6\%), $3(20 \%)$, $1(6.6 \%), 3(20 \%)$, and 1 (6.6\%) for approach 2. Global comparison among all grades was done, and a highly significant $P$-value was obtained $(P$-value $=0.0004$; Table 7 and Figure 3$)$.

\section{Discussion}

Medical students and graduates must be effectively trained to attain the minimum values of medical practice, ${ }^{7,8}$ and didactic precedence in apprentice training must reflect this. It has been documented that medical education has to maintain pace with changing blueprints in the organization and release of patient care. ${ }^{9}$

For this reason, the present study represents the adoption of the evidence-based advance based on the consideration of psychological aspects in the radiology education. The psychological area of learning/teaching has been stressfully conducted in medical education through many studies. ${ }^{10,11}$ Of these psychosocial area, Gestalt theory is considered one of the most interesting theories that connected the visual perceptions particularly in radiology education. Gestalt principles illustrate how the eye perceives visual elements specifically; these principles stated that the complex images tend to be summarized to simpler shapes. Kurt Koffka formulated these principles as: "The whole is other than the sum of parts." This denotes that the whole of an image is perceived as a 
Table 5 The results of two models of questions representing the two approaches

\begin{tabular}{|c|c|c|c|c|c|c|c|c|c|c|}
\hline Model & $A+$ & $\mathbf{A}$ & B+ & B & C+ & C & D+ & D & $\mathbf{F}$ & Independent $t$-test \\
\hline 1 & $\mathrm{I}(\mathrm{I} .6 \%)$ & $4(6.6 \%)$ & $5(8.3 \%)$ & 7 (II.6\%) & $10(16.6 \%)$ & $14(23.3 \%)$ & $12(20 \%)$ & $5(8.3 \%)$ & $2(3.3 \%)$ & \multirow{2}{*}{$\begin{array}{l}P \text {-value is } 0.0000 \mathrm{I} \text {, and it is highly } \\
\text { significant at } P \leq 0.05\end{array}$} \\
\hline 2 & $4(6.6 \%)$ & $8(13.2 \%)$ & $12(20 \%)$ & $17(28 \%)$ & $5(8.3 \%)$ & 7 (I I.6\%) & $5(8.3 \%)$ & $\mathrm{I}(\mathrm{I} .6 \%)$ & I (I.6\%) & \\
\hline
\end{tabular}

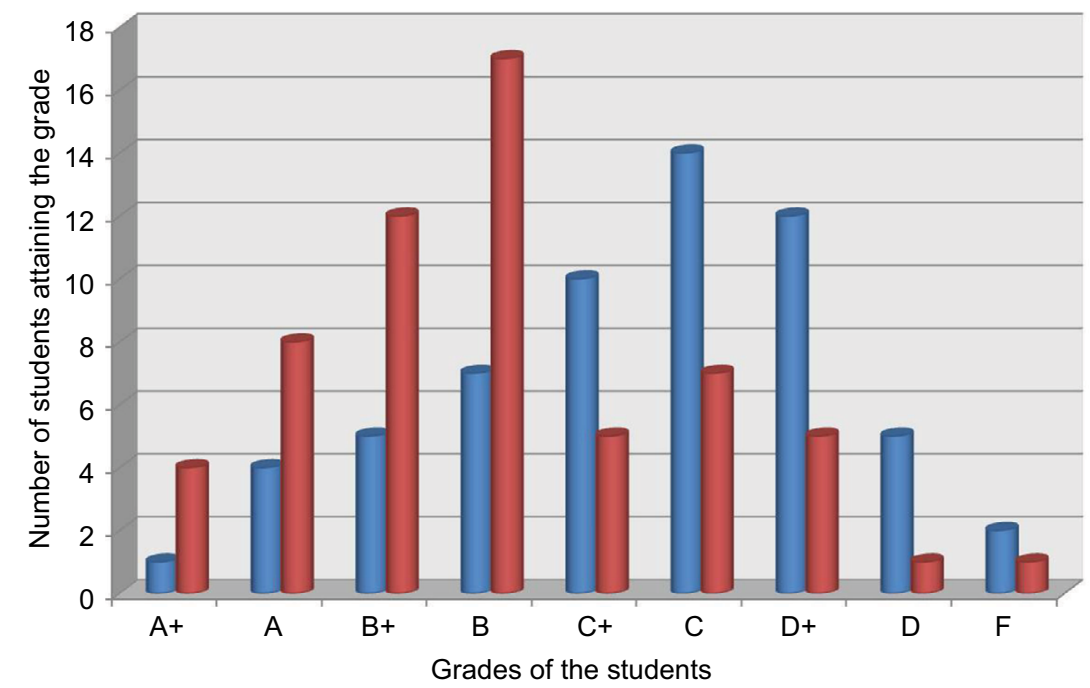

- Model 1

a Model 2

Table 6 The results of the Likert scale about the students' satisfaction against both integration approaches in the basic imaging module

\begin{tabular}{|c|c|c|c|c|c|c|}
\hline Approach & $\begin{array}{l}\text { Strongly } \\
\text { dissatisfied }\end{array}$ & Satisfied & Neutral & Satisfied & $\begin{array}{l}\text { Strongly } \\
\text { satisfied }\end{array}$ & $t$-test \\
\hline 1 & $8(13.3 \%)$ & 7 (11.6\%) & 7 (II.6\%) & $22(36.6 \%)$ & $16(26.6 \%)$ & \multirow{2}{*}{$\begin{array}{l}P \text {-value is } 0.000 \mathrm{I} \text {, and it is significant at } \\
P \leq 0.05\end{array}$} \\
\hline 2 & $4(6.6 \%)$ & $8(13.3 \%)$ & $3(5 \%)$ & $18(30 \%)$ & 27 (45\%) & \\
\hline
\end{tabular}

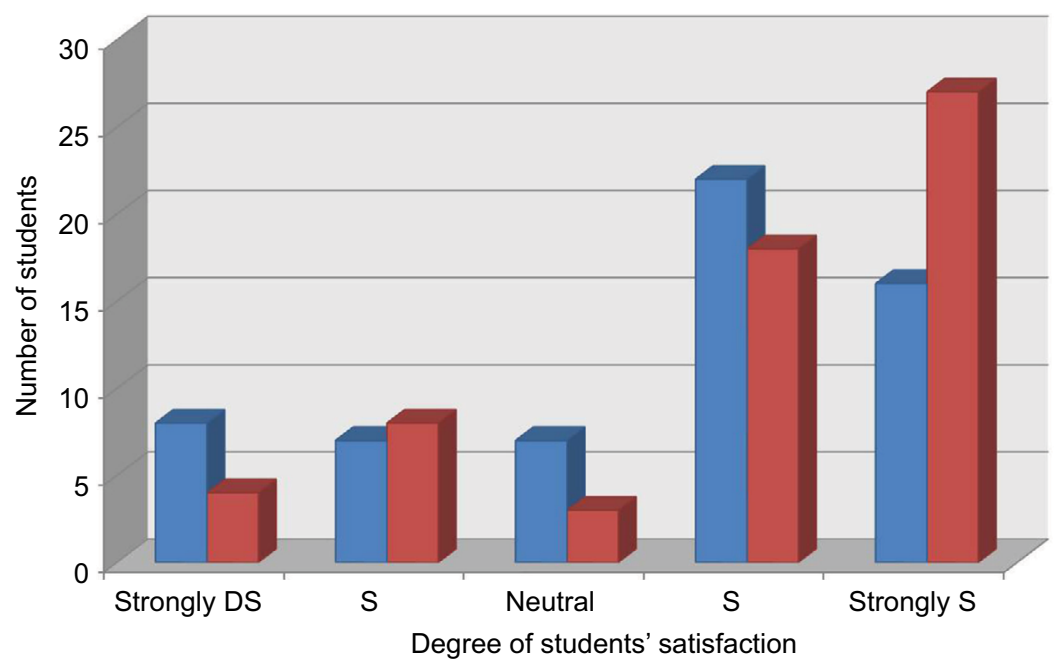

๑ Approach 1

- Approach 2

Figure 2 Students' satisfaction about both integration approaches.

Abbreviations: DS, dissatisfied; S, satisfied. 
Table 7 The results of the Likert scale about the satisfaction of peers against both integration approaches in the basic imaging module

\begin{tabular}{|l|l|l|l|l|l|l|}
\hline Approach & $\begin{array}{l}\text { Strongly } \\
\text { dissatisfied }\end{array}$ & Satisfied & Neutral & Satisfied & $\begin{array}{l}\text { Strongly } \\
\text { satisfied }\end{array}$ & t-test \\
\hline $\mathrm{I}$ & $3(20 \%)$ & $4(26.6 \%)$ & $\mathrm{I}(6.6 \%)$ & $4(26.6 \%)$ & $3(20 \%)$ & $\begin{array}{l}P \text {-value is } 0.0004, \text { and it is } \\
\text { significant at } P \leq 0.05\end{array}$ \\
\hline 2 & $\mathrm{I}(6.6 \%)$ & $3(20 \%)$ & $\mathrm{I}(6.6 \%)$ & $3(20 \%)$ & $7(46.6 \%)$ & \\
\hline
\end{tabular}

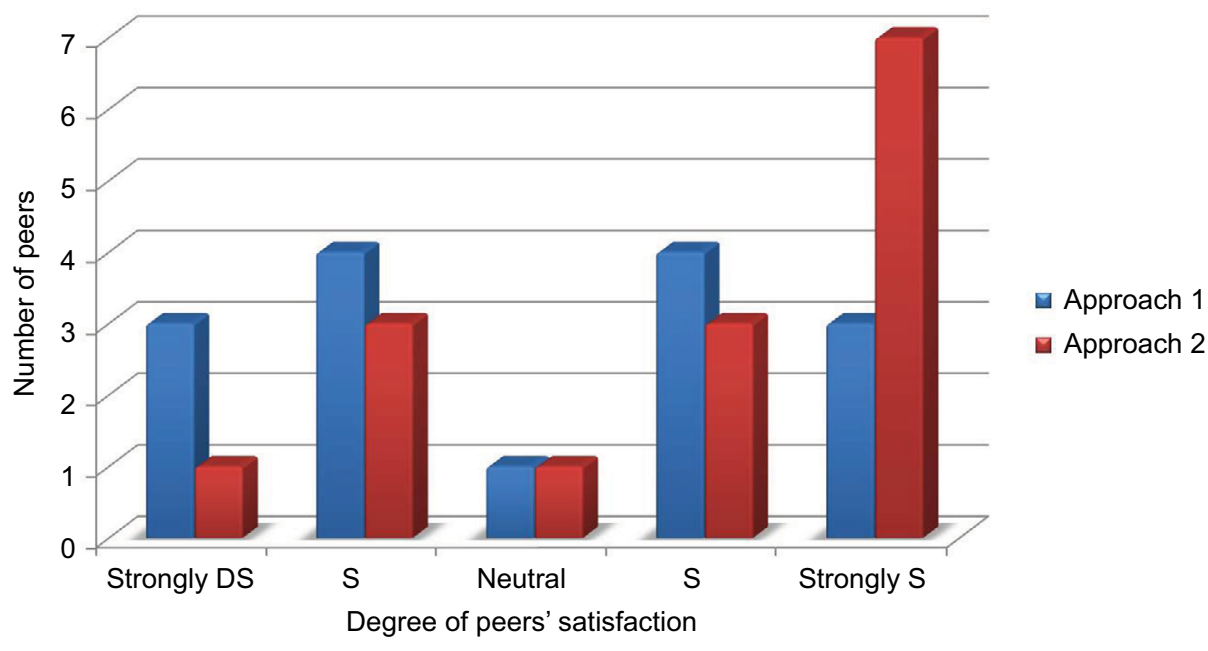

Figure 3 Peers' satisfaction regarding both integration approaches.

Abbreviations: DS, dissatisfied; S, satisfied.

separate entity from its individual parts. Conceptions evoked from Gestalt theory such as the figure-attached relationship and diversity of grouping principles such as similarity of common regions, laws of closure, proximity, continuity, and symmetry are highly precious and invaluable especially in the radiology training. ${ }^{13}$ Connecting these conceptions in the radiology teaching might help the students for better understanding and interpreting the radiology images. According to the Gestalt principle, the author searched for the best way to learn. In compliance with the basic rule of teaching and learning, "the ultimate goal of education is not to teach well, but for learners to learn well."

In the present study, the author compared two approaches of integration in basic imaging module to understand which of them will achieve the goals and outcomes. The first approach is the integration of the imaging modalities under the subject area; the second one is the integration of subject area under one imaging modality. Through this comparative study, the author found a high response from the students toward the second approach of integration, which is the integration of the subject area under one imaging modality. As stated earlier, the grading of students in the second model which was related to the second approach was found high compared with the first model of the first integration approach with highly significant $P$-value obtained. Furthermore, the students' and peers' satisfaction toward the second integration approach was highly compared with the first approach with highly significant $P$-value obtained. These results confirmed that the students can learn radiology better when focused on a single modality for a time. In the second approach, students can identify, augment more images, and do multiple comparisons with the pre and post ones. Augmentation of these images in one or more settings will create a figure-attached student relationship, wherein the student can identify the diversity of grouping principles such as similarity and proximity of common regions which is invaluable especially in the radiology training. ${ }^{13}$

The current study confirmed that most of the students shared in this study had a figure-attached learning style as seen in the previous studies. ${ }^{14,15}$ Accordingly, the results revealed that most of the students best learned by illustrations, figures, and imaging.

Most of the undergraduate radiology programs design the course content as medical subject areas, wherein several imaging modalities describe the findings of the subject area such as imaging trauma patients, in which the plain X-ray, $\mathrm{CT}$, and MRI can discuss the findings. This approach is nearly adopted by many medical schools. ${ }^{16}$

Many teaching approaches were designed by many universities. The University of Virginia designed radiology course which includes the diversity of topics and radiological modalities; the most important of them is the musculoskel- 
etal section. Other programs were produced by the Scottish Radiology Society which adopted radiology course for undergraduate and junior trainees. It is composed of only three topics including head trauma in addition to tutorials composed of a small collection of cases that are a valuable read. In addition to the abovementioned program, there are programs based on many common cases offered with short discussions on each, cases can be investigated through diverse imaging modalities. ${ }^{17}$

\section{Conclusion}

This experience advocated that the perception of students toward radiology teaching can be enhanced when focused on a single imaging modality for a time. The second approach "in which the modalities are addressed as a theme wherein many subjects are described from its radiological aspects" is in favor of both students and peers. Students can identify and augment more images and do multiple comparisons with the pre and post ones.

\section{Disclosure}

The author reports no conflicts of interest in this work.

\section{References}

1. Watmough S, Taylor D, Ryland I. Using questionnaires to determine whether medical graduates' career choice is determined by undergraduate or postgraduate experiences. Med Teach. 2007;29(8):830-832

2. Gunderman RB, Alexander S, Jackson VP, Lane KA, Siddiqui AR, Tarver $\mathrm{RD}$. The value of good medical student teaching: increasing the number of radiology residency applicants. Acad Radiol. 2000;7(11):960-964.
3. Boynton PM, Greenhalgh T. Selecting, designing, and developing your questionnaire. BMJ. 2004;328(7451):1312-1315.

4. Boynton PM. Administering, analysing, and reporting your questionnaire. BMJ. 2004;328(7452):1372-1375.

5. Rattray J, Jones MC. Essential elements of questionnaire design and development. J Clin Nurs. 2007;16(2):234-243.

6. Derrick B, White P. Comparing two samples from an individual Likert question. Int J Math Stat. 2017;18(3):1-13.

7. Academy of Medical Royal College [webpage on the Internet]. Foundation Curriculum. Available from: http://aomrc.org.uk/curriculum and framework/curriculum.html. Accessed December 5, 2017.

8. General Medical Council [webpage on the Internet]. The Trainee Doctor. Available from: www.gmc-uk.org/Trainee_Doctor. Accessed December, 2017.

9. General Medical Council. The State of Basic Medical Education. London: GMC; 2011:p49e50.

10. Barzansky B, Etzel SI. Educational programs in US medical schools, 2003-2004. JAMA. 2004;292(9):1025-1031.

11. Barzansky B, Jonas HS, Etzel SI. Educational programs in US medical schools, 1998-1999. JAMA. 1999;282(9):840-846.

12. Koffka K. Principles of Gestalt Psychology. London: Routledge; 1935:176.

13. Lass P, Scheffler J. Undergraduate teaching of nuclear medicine in European universities. Eur J Nucl Med Mol Imaging. 2003;30(7):1018-1023.

14. Atta IS, Alqahtani FN. How to adjust the strategy of radiopathologic teaching to achieve the learning outcomes? Int J Med Sci Public Health 2018;7. 2018;1130015122017.

15. Atta IS, Alqahtani FN, Alghamdi TA, Mankrawi SA, Alamri AM. Can Pathology - Teaching' Strategy be Affected by the Students' Learning Style and to what extent the Students' Performance be Affected? Glo Adv Res J Med Med Sci. 2017;6 ((11):296-301.

16. Mirsadraee S, Mankad K, McCoubrie P, Roberts T, Kessel D. Radiology curriculum for undergraduate medical studies - a consensus survey. Clin Radiol. 2012;67(12):e1155-1161.

17. Shah M, Muquit S. Radiology teaching material. The Annals of The Royal College of Surgeons of England. 2007;89(3):325.
Advances in Medical Education and Practice

\section{Publish your work in this journal}

Advances in Medical Education and Practice is an international, peerreviewed, open access journal that aims to present and publish research on Medical Education covering medical, dental, nursing and allied health care professional education. The journal covers undergraduate education, postgraduate training and continuing medical education

\section{Dovepress}

including emerging trends and innovative models linking education, research, and health care services. The manuscript management system is completely online and includes a very quick and fair peer-review system. Visit http://www.dovepress.com/testimonials.php to read real quotes from published authors. 